EGU2020-3676

https://doi.org/10.5194/egusphere-egu2020-3676

EGU General Assembly 2020

(c) Author(s) 2020. This work is distributed under

the Creative Commons Attribution 4.0 License.

\title{
A tribute to Marie Tharp: Mapping the seafloor of back-arc basins, mid-ocean ridges, continental margins and plate boundaries
}

\author{
Eulàlia Gràcia ${ }^{1}$, Sara Martínez Loriente ${ }^{1}$, Susana Diez ${ }^{2}$, Laura Gómez de la Peña ${ }^{3}$, Cristina S. Serra ${ }^{1}$, \\ Rafael Bartolome ${ }^{1}$, Valentí Sallarès ${ }^{1}$, Claudio Lo lacono ${ }^{1}$, Hector Perea ${ }^{4}$, Urgeles Roger ${ }^{1}$, \\ Grevemeyer Ingo ${ }^{3}$, and Cesar R. Ranero ${ }^{1}$ \\ ${ }^{1}$ Institut de Ciències del Mar - CSIC, Barcelona, Spain (egracia@icm.csic.es, smartinez@icm.csic.es, csserra@icm.csic.es, \\ rafael@icm.csic.es, vsallares@icm.csic.es, loiacono@icm.csic.es, urgeles@icm.csic.es, cranero@icm.csic.es)) \\ ${ }^{2}$ Unitat de Tecnologia Marina - CSIC, Barcelona, Spain (sdiez@utm.csic.es) \\ ${ }^{3}$ GEOMAR - Kiel (Germany) (Igomez@geomar.de, igrevemeyer@geomar.de) \\ ${ }^{4}$ Universidad Complutense de Madrid, Madrid (Spain) (hperea01@ucm.es)
}

Marie Tharp (1920-2006) was a pioneer of modern oceanography. She was an American geologist and oceanographic cartographer who, together with his husband Bruce Heezen, generated the first bathymetric map of the Atlantic Ocean floor. Tharp's work revealed the detailed topography and geological landscape of the seafloor. Her work revealed the presence of a continuous rift valley along the Mid-Atlantic Ridge axis, causing a paradigm in earth sciences that led to the acceptance of plate tectonics and continental drift theories. Piecing maps together in the late $1940 \mathrm{~s}$ and early 1950s, Marie and his partner Bruce Heezen discovered the $75.000 \mathrm{~km}$ underwater ridge bounding around the globe. By this finding, they laid the conclusion from geophysical data that the seafloor spreads from mid-ocean ridges and that continents are in motion with respect to one another-a revolutionary geological theory at that time. Many years later, satellite images demonstrate that Tharp's maps were accurate. In this contribution, we focus on detailed bathymetric maps collected from year 1992 to today, which include bathymetric maps from diverse parts of the world. For instance, we will show a) Back-arc basins (i.e. the Bransfield Basin, Antarctica; and the North Fiji Basin, SW Pacific); b) Mid-ocean ridges and fracture zones (i.e. the MAR at the South of Azores, the MAR at the Oceanographer-Hayes, and the St. Paul Fracture Zone at the Equator), and c) Active tectonic structures from the Gulf of Cadiz and Alboran Sea, located at the Africa-Eurasia plate boundary (Gibraltar Arc). Regarding this last area, we will characterize the seafloor expression of the fault systems, as well as the subsurface structure of the faults in the Gulf of Cadiz and Alboran Sea. This zone is characterized by a moderate seismicity, mainly reverse and strike-slip focal mechanisms; although large historical (AD1755, AD1829) and instrumental earthquakes or large/great magnitude also occurred, such as the earthquakes of 1969, 1994, 2004 and 2016. In addition, the Gulf of Cadiz-Alboran Sea area is compartmentalized in different crustal domains, bounded by active strike-slip fault systems. We adopted a multi-scale approach, including morphological analysis of shipboard multibeam bathymetry, near-bottom bathymetry obtained with Autonomous Underwater Vehicles (AUVs) at a resolution of 1-2 m, and medium to deep penetration multi-channel seismic (MCS) data. Finally, we will also show a couple of videos 
from recent marine cruises in the Gibraltar Arc (SHAKE-2015 and INSIGHT-2018), both using stateof-the-art high-resolution marine technologies. 